\title{
CATHOLIC NUNS AND ENGLISH IDENTITIES. ENGLISH PROTESTANT TRAVELLERS ON THE ENGLISH CONVENTS IN THE LOW COUNTRIES, 1660-1730'
}

\author{
by Liesbeth CoRens
}

I took the opportunity, my Lord, this last summer when I was in Flanders to get an exact calculation of all the English seminaries in the Low Countries in order to show Her Majesty by your Lordship the root from whence this great growth proceeds, which sends us such numbers of tourists and gentlemen brought up in an aversion to our civil and religious constitution, and which carries such immense sums out of England, and does more than anything keep up our unhappy divisions amongst us.

$\left(\right.$ John Macky, 1707) ${ }^{2}$

The English have also here [Aire-sur-la-Lys] a nunnery for ladies, call'd the poor clares; and poor they are indeed! For they have two bare-footed Friars to go about de country every morning to beg provision for them, who never miss in coming into the publick inns, when they hear of the arrival of an Englishman. I went to deliver my charity out of my own hands, which I put into a wheel that turned round, but could not see any of their faces, only the lady that received the bounty, told me that she was a daughter of Lord Widdrington.

$(\text { John Macky, 1725) })^{3}$

B oth text fragments are from the hand of the same author: John Macky. Macky wrote the first fragment while he was spying on the Jacobite network in the Southern Netherlands for William and Mary. The convents were depicted in his report as an acute danger to the wellbeing of England, since they drained money from the isle and created a permanent flow of dangerous Catholics, 'educated in an aversion to our ecclesiastical and civil constitution'. The second fragment is taken from the bestselling travel guide Macky wrote nearly two decades later. ${ }^{5}$ In stark contrast to his gruesome warnings made as a spy, he heartily recommended his readers visit the convents. Macky implicitly encouraged his readers to pass over the local religious communities and turn their attention towards the English foundations. Accordingly, his guide is punctuated by sentences such as 'here are abundance of religious orders, especially two nunneries of English ladies', 'of the many nunneries that are here, there are two English', and 'here are abundance of cloisters of men and women; and amongst the rest, a nunnery of English ladies'. ${ }^{6}$ As a spy he had only outwardly observed the different convents, whereas in his travel guide he stressed how very agreeable the personal contact with 
the ladies was. In Antwerp for instance, the prioress of the English Carmelites, Mrs. Bond, was characterized as "very courteous to her countrymen'. 'Lucy Herbert, abbess of the English Augustines in Bruges was equally 'a Lady of great affability and civility to the English'.

Macky's ambiguous remarks on the convents in the Southern Netherlands preface this paper since they suitably illustrate its topic: the convents were reckoned dangerous hotbeds of popery, yet at the same time they were among the travellers' favourite and most highly appreciated attractions. Very few English Protestants touring the Low Countries omitted a visit to them, spending an hour or two at the grate talking to the nuns, drinking tea with them, and occasionally buying some of the artefacts they had produced. ${ }^{9}$ These encounters took place among societal equals. After all, the inhabitants of the nunneries belonged to the highest gentry families, and - despite strict Tridentine regulations of enclosure - they maintained extensive patronage networks. ${ }^{10}$ The travel writers, who were also mostly upper class, moved in the same high circles, and thus paid a visit to women whose family and connections they were familiar with.

Thus far, these visits have not received close attention, at least not from the perspective of the travellers. Some historians have deduced information about the organisation of the nunneries themselves, and the effectiveness of their enclosure. ${ }^{11}$ The nuns' motives for receiving the visitors have also been analysed, disclosing the entertainment at the grate as a deliberated proselytizing strategy. As Claire Walker has pointed out, the women could barely expect the Protestant travellers to act as patrons-which was an incentive for welcoming unknown Catholic travellers who thereby got firsthand experience of the nuns' politeness and pressing financial needsso the effort they made in obliging them, served some other purposes, and among these an urge to proselytize was a prominent one. ${ }^{12}$

The other side of the encounter, however, the Protestant experience, is the subject of this article, since it offers an interesting test case for national identity. ${ }^{13}$ In visiting the nunneries, which most travellers did, they placed themselves in an ambiguous position between religious and national identity. Dominant English identity formation, after all, did not include Catholics, and was even positively antagonistic towards them. How did these issues of identity politics influence the experiences of the Protestant travellers? Was the religion of the Catholics too great an obstacle, and did the travellers therefore regard them as strangers? Or did they, in a foreign country with a strange language, strange culture and strange values, discover small patches of familiar Englishness?

In search of answers to these questions, thirty travel narratives, produced between 1660 and 1730 have been examined. The start date was chosen because by 1660, English travel properly took off. Picking 1730 as the end date ensured a homogeneous collection of source material, for after the 1720s English public opinion towards Catholics had quietened considerably. In the aftermath of the defeat of the Jacobite 
raising (1715) and failure of the Atterbury plot (1722), the decade witnessed the dawning of a new and calmer stage in the development of Protestantism's relationship with Catholicism. ${ }^{14}$ Therefore, by opting for 1730 as the terminal publication date, the travellers all came from a similar background. Ten of the narratives were published in the Early Modern period as travel guides, either as independent publications, or as parts of collections. The remaining twenty did not make it to the press until the twentieth century and range from personal diaries to letter collections to businesslike narratives. Eventually merely ten of these will be cited frequently, as they offered the most colourful statements. Even though this is a small and varied selection of sources, the texts are representative of many English travellers in the Southern Netherlands, for the wide circulation of both printed and manuscript texts among friends and family, meant that these did shape the experiences of travellers. Frequently the authors of personal diaries visited the same places, discussed the same subjects and uttered the same opinions as the ones recorded in travel guides. Sometimes, they even bluntly copied passages. ${ }^{15}$

Based on these sources, it will be argued the predominant stance among historians, favouring anti-Catholicism as the foundation of English national identity, is too simplistic an interpretation. The travellers' description of the English nuns could have been an excellent opportunity for repeating juicy stereotypes, elaborating their English and anti-Catholic identity. Yet within the context of a strange continent, the travellers recognised the nuns as compatriots, and refrained from mocking them. The travel narratives may therefore illustrate that this negative identification is merely one aspect of a more complex Englishness. In order to grasp this, firstly the widespread idea of linking English national identity and anti-Catholicism will be discussed. Secondly, it will be noted how antiCatholic stereotyping is absent from the travel accounts and how the convents were not even represented as Catholic nunneries. Their actual representation will be addressed in the third part. The travellers portrayed them not as Catholic material convents, but as English human communities, and found a shared feeling of Englishness, crossing the confessional divide.

\section{Anti-Catholicism and English National Identity}

Historians of English identity have accorded great importance to antiCatholicism, for a common theory holds that each characteristic attributed to 'the other' implies by reversal a positive description of oneself. In Anglican religious identity the spectre of Catholicism served this purpose. Accordingly, Catholicism was described as an anti-religion and a negative image of true Christianity, ${ }^{16}$ which was continually bombarded on the average Protestant Englishman by means of news papers, popular 
print, almanacs, Sunday sermons, the ritual calendar, and monuments, amongst other things. ${ }^{17}$

A central feature in this anti-Catholic rhetoric was the notion of a national identity. Looking for the roots of nascent nationalism in the seventeenth century, historians invariably point to the importance of religious convictions, as many European states had connected the interpretation of their history to one branch of Christianity. ${ }^{18}$ In England's case, this was Anglicanism; being English, meant being Protestant, and therefore non-Catholic. However, historians do not quite agree on the exact force of negative identification. While Linda Colley's influential work argued that the anti-Catholic mentality was what separated eighteenth-century Britain from Catholic Europe ${ }^{19}$ her ideas have been nuanced considerably. Jonathan Clark, for instance, has second thoughts about the conclusiveness of anti-Catholicism, and stresses that Protestants on the British Isles were desperately divided among themselves, despite a common enemy. ${ }^{20}$ Furthermore, as Tony Claydon has demonstrated, negative identification is only one part of the story, and there is considerable evidence of positive identification with Protestant Europe. ${ }^{21}$ The reduction of English national identity and confessional identity to a direct relation has moreover been questioned by Jeremy Black. ${ }^{22}$ Nonetheless, it is generally accepted that anti-Catholicism did play at least some part in the Englishman's identification with his country. The English were proud of their categorically non-Catholic country. ${ }^{23}$

One could discern two broad manifestations of anti-Catholic national identity. Firstly, it functioned as a mechanism of inverted self-advocacy. ${ }^{24}$ Whenever Protestant England defined what it stood for, it contrasted itself with Catholic Europe. By stereotyping all hated aspects of the Catholic continent, Protestant England demarcated the borders of its own position; it literally defined itself. ${ }^{25}$ The second variant of antiCatholicism stressed the incredible danger Catholics posed, presenting England's history in a providential light: thanks to God's persistent help, the nation had frequently been saved from Catholic peril. The victory over the Spanish Armada and the timely discovery of Gunpowder Plot had all been part of God's plan, ${ }^{26}$ as were later events, such as the defeat of the Jacobite rebellions, which were added to the line of providential escapes. ${ }^{27}$

In an antithesis to the conception of Protestantism as 'English', Catholicism was represented as thoroughly continental and un-English. ${ }^{28}$ Accordingly, polemics dwelled less on doctrinal errors, and more on Catholics' bonds with foreign powers. ${ }^{29}$ By stressing the part they took in the international danger, the English followers of Rome were attributed a cosmopolitan character, separated from the isle. This accusation of an international character manifested itself in the language used to describe them, for adjectives such as 'hispaniolized' and other variants often accompanied the mention of Catholics, only outstripped in frequency 
by the adjective 'outlandish'. Cromwell, for one, was convinced that 'the Papists in England have been accounted Spaniolised ever since I was born'. ${ }^{30}$ Likewise, the current designations 'papists' and 'romanists', not only enclosed theological accusations - Catholic faith would have centred around the Pope, not Christ — but also had a geographical association: Catholics served a foreign prince. ${ }^{31}$ So a children's song in the $1650 \mathrm{~s}$ ran 'Papist, Papist, pray to the Pope, your neck a halter, your heels in a rope ${ }^{32}$ while the nervousness about the implications of (dis)loyalty in the use of terminology is reflected in Catholics' disassociation from these terms. When, for instance, during the Civil War, Arthur Bell had acknowledged to his interrogator that he was a Catholic, and was asked whether he was a Roman Catholic, he replied: 'How do you mean, Roman? I am an Englishman. ${ }^{33}$

Thus far, only one aspect of national identification has been discussed. Though very important, this anti-Catholicism was nonetheless only one aspect of a complex network wherein English people defined themselves in different and often conflicting ways. ${ }^{34}$ Therefore, Mark Netzloff prefers the term 'Englishness' instead of 'English nation', thus implying a loose identification, subject to different possibilities of interpretation. ${ }^{35}$

One possible interpretation is the Catholic one, which is often overlooked. Even Tony Claydon, whose innovative approach overcomes the insularity of English historiography, does not take into account the possibility of Catholic Englishmen, even though they in particular were notorious for their continental contacts. ${ }^{36}$ Catholicism was, however, not as international a religion as Protestant propaganda tended to proclaim. 'Transnational' would cover its position in a more appropriate way. Catholics were part of a worldwide community, but never fully annihilated national frontiers. ${ }^{37}$ On the contrary, English Catholics purposefully maintained a national character. ${ }^{38}$ They stressed that the Old Religion had always been the core of English identity, thereby acting in the same way as Anglicans: they both excluded the other confession from their interpretation of national identity. Beda Venerabilis' history served this interpretation best, and particularly Augustine's mission from Rome to the British Isles was deemed an essential moment in England's formation. This way, the link with Rome was decisive from the very beginning of Christianity in England. Others emphasized the Saxon and Germanic roots of the English nation. The preservation of these characteristics despite the Norman conquest, offered a hopeful prospect for the future of Catholicism after the Protestant 'invasion'. 39

This non-Protestant English national identity was part of the selfdefinition of the English convents in the Southern Netherlands. Their members' allegiance to the universal Catholic Church was only of secondary importance, as their first and foremost loyalty lay with the English Catholic community. ${ }^{40}$ The nuns awaited the recatholisising of England, and their ensuing re-migration. In order to be acceptable on 
return, the convents deliberately maintained an outspoken English identity, and refused to assimilate. ${ }^{41}$ They were 'little self-enclosed Englands that shut out the foreign cultures around them', to quote Christopher Highley. ${ }^{42}$ Isolation from the surrounding environment was realized through the convents' persistent use of the English language, and maintenance of an exclusively English population - apart from laysisters who took care of logistical tasks. ${ }^{43}$ The nunneries further preserved their Englishness in asserting their continuity with ancient English tradition, opting for paintings of early Christian English kings, or the veneration of exclusively English saints. ${ }^{44}$

\section{Catholic Convents?}

Encountering the English nunneries could have enticed the travellers into bluntly repeating age-old stereotypes scoffing the Catholics. The nuns, after all, served as a shorthand for the irrationality, immorality and slavish obedience Anglicans attributed to the entire Catholic community, thereby defining what the rational, virtuous and individual English Protestant was not. Yet the travellers did not abuse the obvious opportunity to elaborate their anti-Catholic identity. They even showed deep respect for the women they encountered.

One of the more prominent stereotypes surrounding the convents, was that they were populated by ignorant and naive women. The nuns were depicted as unable to think for themselves, damaged by their unhealthy subservience to male superiors. In this perspective, the nunnery was the antithesis of the rational and enlightened Protestant. ${ }^{45}$ Visiting the Southern Netherlands, however, did not lure the travellers into repeating this stereotype. Quite the contrary, the nuns in the travel accounts are depicted as interesting conversational partners. Harwood for instance, wrote in 1697 that he was received by the Benedictine nun Mrs. Mary Knatchbull 'who seem'd to be a lady of good witt \& senses' ${ }^{46}$ Joseph Shaw visited her well over ten years later, and engaged in conversation for around two hours. Afterwards, he was convinced that he would always remember their conversation as 'one of the most agreeable of my whole life'. ${ }^{47}$

A second widespread stereotype portrayed the nunneries as quasiprisons, where the poor girls were confined against their will, left to the mercy of corrupt superiors and lustful confessors, and thus signifying the immorality of the Catholic church. Writing about the SouthernNetherlandish cloisters in 1685, William Carstairs did indeed notice this flaw. He claimed the women were 'forced by their parents to take that course of life'. ${ }^{48}$ Nonetheless, he did not make a comparable negative judgement on the English communities. Only one anonymous traveller hinted at the possible submission of the girls in recounting an eyewitness account on a profession of three English ladies: 'and their heads being 
shaved, these poor deluded women put on the habit and quit the world' ${ }^{49}$ He was, however, alone in making such comment. Even the polemical equation of the cloister grate with a prison grate was repeated by no more than one of the travellers. Only John Macky wrote about the Carmelite cloister in Antwerp that 'the grates are so dismal, that it looks like a prison'. Nevertheless, he also noted about the same cloister that the prioress was 'very courteous to her countrymen'. ${ }^{50}$ During the remainder of his travels, no other negative comparisons were made. For most travellers, the grate represented a point of contact with the outside world, rather than a symbol of seclusion. It was 'through an iron grate' in the nunnery in Dunkirk that Philip Skippon 'had freedom to see and discourse with them'. ${ }^{51}$ He noted down this experience once more, as in Ghent as well, he had been able to freely converse with the abbess and nuns 'thro' a grate in their parlour'. ${ }^{5}$ Many other travellers likewise mentioned the grate without making the slightest negative judgement on it. ${ }^{53}$

A third group of negative stereotypes on the nuns in the English imagination clustered around the vow of celibacy. On the one hand, the imposition of celibacy and enclosure ran contrary to nature, and seventeenth-century satire often stated that an attractive nun or priest was a waste. From a very economical perspective, after all, the enclosed women contributed little to society, both in terms of reproduction and community welfare. ${ }^{54}$ However, the breaking of the vow was deemed just as reproachable as the taking thereof, for it offered yet another example of the general untrustworthiness of Catholics. Given the political preoccupations with Jacobitism, this fixation on Catholic disloyalty was the more pronounced in the decade after the Glorious Revolution. ${ }^{55}$ It is therefore highly interesting to note that the travel accounts rarely touched upon these matters. Some travellers did express some despair about the fact that dashingly beautiful women were lost to the world, but did this in a nuanced way. Thomas Penson's 1687 account offers the most outspoken example. He had been introduced to an English nun in Antwerp, whom he described as 'an angel of light'. His admiration lead him to admit to the girl he was disappointed she would enclose herself in a cloister 'for we account it no less than being buried alive to be immured within the confines of these walls'. Though he resented cloistered life, he did not refrain from taking note of her positive answer without further comment. She had ensured him she was perfectly happy, and would not swap her existence for that of a princess. ${ }^{56}$

Even more significant than the lack of negative denunciation, is positive approval. Some travellers judged the idea of enclosed female communities to be worthwhile. For instance Joseph Taylor, on crossing the channel in 1707, met with three good-looking female compatriots, and, suspecting they envisaged to enter a nunnery, he attempted to dissuade them from furthering their plans. ${ }^{57}$ Yet, when he ran into them for the third and 
last time in Brussels, and was forced to witness they had not complied with his pleas, he did not judge it inappropriate that he 'began to preach up the pleasures of a retired life, free from the cares and perplexities of a troublesome world', the reason being 'so much virtue, beauty and good nature must be cloistered. ${ }^{58}$

This positive connotation of the confinement of women from the tumultuous world, was not uncommon within the Church of England. ${ }^{59}$ Many authors, such as Mary Astell, George Wheler and Daniel Defoe, wrote in favour of the idea, and developed plans for a Protestant variant of a female refuge, both fictional and practical. They explicitly disassociated themselves from Catholic foundations by stressing the voluntary nature of their own creations. Gilbert Burnet's words are most revealing, in that he defined his working concept as 'something like Monasteries without Vows'. ${ }^{60}$ Vows, so they reasoned, would signify an imposition of piety, whereas the Protestant faith was convincing in itself. ${ }^{61}$ For Mary Astell in particular, there were to be no eternal vows, since the education and pious life provided in the institutions was explicitly aimed at turning the women into useful members of society. Therefore, the retirement should only be temporary, and the women should be able to leave the communities any time they wanted, backed with knowledge they had gained in the meantime. ${ }^{62}$

Interesting in this respect are the travellers' description of beguinages. They do not strictly fall within the confines of this paper, as they were inhabited by Southern-Netherlandish women. Yet briefly touching upon the appraisal of the beguines discloses that the travellers subscribed to the favourable Anglican ideas on female communities outlined above. Beguines do not take the vow of enclosure like nuns do. Consequently, they avoid what Protestants reckoned the most revolting aspect of nuns' lives, which might explain why beguines were never put into bad light. ${ }^{63}$ This particularly holds for John Leake's musing in the beguinage in Louvain in 1711, confiding to his readers that 'an institution somewhat like this for ladies of good family, but a small fortune, would not be amiss, even in a reformed country'. ${ }^{64} \mathrm{He}$ explicitly put stress upon what concerned Protestants most: the beguines were not irreversibly lost to the world, but were free to leave the community whenever they had set their mind on getting married. ${ }^{65}$

In short, travellers did not appear to have taken the opportunity to use the convent as a stock figure against which to define their own English identity. What is more, none of the travellers so much as hinted at a disapproval of the religion of nuns. In fact, they even barely made reference to the women's religion, often omitting mention that the convents were Catholic. This could obviously be explained by the matter-of-factness of the confession of the nuns, as convents were more or less a landmark of Catholicism. Yet one cannot help but wonder at the sheer indifference about the fact that the visit of a Protestant compatriot might pose some 
inconvenience in a Catholic community. Only John Macky hinted at this potential awkwardness, remarking that the abbess in Antwerp was extremely polite towards every English visitor 'be they of what profession they will'. ${ }^{66}$

This lack of preoccupation with religious frictions is the more significant since the visits to the male foundations did trigger thoughts of their confessional quarrels. While the friendly reception in the female convents was taken for granted, many travellers were astonished to be treated so well in their male counterparts. Joseph Shaw, for instance, remarked on the conversations he had had in Saint Omer that 'tho' they knew me a Protestant, yet they received me with all the civility and address that insinuates into the heart. ${ }^{67}$ John Northleigh similarly wondered at the ease with which a conversation that might have been awkward had taken place. During his visit to the English Jesuit college in Liège he noted that 'our countrymen there carry'd themselves very kindly to those of their country that came to see them; and tho' we differ'd in opinions, we cou'd agree in conversation' ${ }^{68}$

The content of these is not often disclosed. From the rare scraps of conversation handed down to the twenty-first century, however, it seems religion was not very often a part of it. The nuns did make an effort to convince their visitors of the benefits of their religion. ${ }^{69}$ In John Percival's experience, they even did this very frequently. To the extent that on recording his visit to Mary Knatchbull in Ghent in 1718, he commented that 'she could not forbear entering into controversy which is the common weakness of these female societies'. ${ }^{70}$ At least in his opinion, conversations like these were not unique. Other travellers, however, did not often refer to any, let alone express negative feelings about them. Upon Philip Skippon's visiting the Benedictines in Ghent in 1664, they attempted to convince their compatriot of the force of their church by confronting him with the beneficial wonders God bestowed upon them. During his conversation with one of the nuns, Mary Minshull, he was given 'a printed paper of her being miraculously cured of lameness etc by using some of the oil in a lamp that hangs before the altar of Our Lady of Succour's chapel in Brussels; she was cured 26th of August 1660,71 Though Protestantism notoriously defied Catholic claims to miracles, Skippon did not make any negative comment on Mary Minshull's account. He even deemed it interesting and appropriate to visit the said chapel when he passed through Brussels. ${ }^{72}$ Two decades later, in 1687, the Antwerp nuns managed to encourage Thomas Penson to develop more than mere curiosity for a miraculous chapel. Once his conversational partner had understood Penson professed the Protestant religion, she had answered 'I am sorry', and advised him to turn to 'that Church wherein salvation is only to be obtained'. He had answered that his stay on the continent had brought him into contact with a lot of Catholics who had made him scrutinize 
his own religious convictions. ${ }^{73}$ These examples, however, are exceptional, and on the whole travellers did not deem it interesting to make mention of confessional conversations.

\section{English Communities}

The travellers placing little emphasis on what separated them and nuns, serves as an indication of the nature of the contacts they had. They did not meet as confessional enemies, but as compatriots. Accordingly, the travellers represented the nuns as genuinely English. Their description of the nuns as members of 'our nation' or 'our countrywomen' can be called at least remarkable. ${ }^{74}$ The very fact that they were countrywomen was the nuns' main asset. Significant in this respect is the observation that travellers in Italy scoured uncountable Italian houses admiring the treasures, ${ }^{75}$ yet passed over the local communities in the Netherlands. Here they had more interesting places to visit: English sisters. Their presence even made the travellers forget all about the wealth the nuns possessed, turning their attention wholly to personal contact with fellow English.

Travellers were interested not so much in the convents, consisting of mere material buildings, as in the human communities of English women. It is for example highly unusual to come across any description of the materiality of the cloister in the travel accounts. Only Thomas Scott's discussion of the chapel in Dunkirk in 1672 is an exception to this, as he merely described its beauty, although this brevity may be due to the fact that he had not had the chance to talk to the religious. ${ }^{76}$ In 1697, Harwood also gave a fairly elaborate description of the Dominican cloister in Brussels, but this outward presentation was followed shortly afterwards by an account of a personal conversation with the nuns. For Harwood as well, the visit was mainly about the women, not the buildings. ${ }^{77}$

Even the shortest of descriptions put the religious women at the centre of all attention. ${ }^{78}$ Joseph Shaw for instance, limited his 1709 account of the English presence in Brussels to: 'one English Nunnery of Clares, and one of Dominicans, who entertain'd me with much civility'. ${ }^{79}$ The choice of verbs also precludes an active interaction. Travellers did not just 'look at' the cloisters, as they sporadically did with Southern Netherlandish houses. They 'waited upon', 'call'd in at', 'payed a visit to', and 'paid respect to' the religious women. ${ }^{80}$

The focus on human contact with the English nuns becomes even morepronounced by comparing the travellers' descriptions of English convents with their-rather rare - descriptions of Southern-Netherlandish convents. In stark contrast to the interactive visits of the English convents, the local convents were depicted in purely material terms, merely noticing the riches. John Macky's account offers the clearest illustration thereof. Breaking off his journey along the well-known towns of the Southern 
Netherlands, he sometimes made short excursions to the countryside to visit local religious foundations. ${ }^{81}$ The abbeys 'very well deserve seeing', in his opinion. ${ }^{82}$ Once more, the use of the verb is highly significant: the local institutions were mere objects of sightseeing. Accordingly, Macky's description of these places exclusively incorporates materialistic aspects of the buildings, ${ }^{83}$ they might as well have been uninhabited, for the buildings' occupants attracted none of his attention. Contrastingly, when discussing the English communities, Macky focused on the nuns themselves. For instance, he covered the English presence in Bruges with the words: 'Of the many nunneries that are here, there are two English, one Augustines, who are all English Ladies of Quality, whose superior is, at present, Lady Lucy Herbert, sister to the Duke of Powis; a Lady of great Affability and civility to the English, be they of what profession they will; they entertain you at the grate with sweet-meats and wine ${ }^{84}$ In Antwerp as well, Macky was solely interested in the lives of the women rather than in the buildings they shared: 'here are abundance of nunneries; amongst others, an English one, of the Order of St. Tereza; they never wear linnen, nor eat flesh, and lie upon straw. The present prioress, Mrs. Bond, a grand-daughter of my lord Jermin, is very courteous to her countrymen'. 85

In short, the travellers recognized the nuns as countrywomen, and they gave this recognition expression in stressing the common ground they shared. The conversations mentioned above on what separated the travellers' world from the nuns' world were highly uncommon. Travellers preferably put stress upon the conversations they had concerning what the two conversational partners shared. In 1687, for instance, Thomas Penson discussed the recent developments in their home country, "how the King [James II] did and how all things were in England' ${ }^{86}$ The nuns of travel accounts were not portrayed as strictly religious, but as women of the world, who were well acquainted with what happened outside their cloister walls. During his travels in 1711, John Leake even expressly commented upon the nuns' ability to have engaging conversations: 'their conversation being easy and genteel and their conduct wholly disengaged from the stiff and precise'. ${ }^{87}$

Apart from their mutual interest in developments back in England, travellers and nuns shared something very important: English connections. The religious women themselves were firmly encapsulated within well-known families, which the travellers acknowledged by consistently identifying them by their family names, which, again, they did not do for local nuns. This explicit connecting with English families seems the antithesis of denying the English character of Catholics, and categorizing them as foreign and continental. Instead, the nuns were acknowledged for their moving in the same high circles as travellers. Interestingly, the extensive English merchant communities were barely mentioned, though this lack of reference does not necessarily mean travellers did not visit them, 
since individual encounters were rather sporadically described in the travel narratives. After all, most of the studied texts were aimed at wider circulation, and therefore merely took into account what was worth a visit. As opposed to the merchants who lacked any clear permanent point of reference, the nunneries offered enduring bench-marks, worthy mentioning in a travel guide. It is therefore not surprising that the descriptions of individual English are chiefly to be found in the personal diaries and letter collections. ${ }^{88}$

The family names and roots on English mainland turned out to be crucial in the encounters. In order to gain access to the communities, travellers were obliged to fall back on contacts. This tactic obviously served the purpose of fencing off the communities from the outside world. Yet the outside world turned out to be mainly the non-English world, as travellers were often able to enter the communities by means of their English bond. Thereby the idea of connectedness through national identity was obviously enhanced. In order to enter the cloisters, most travellers claimed acquaintance with the confessor or some member of the community. Others had obtained a letter of recommendation. ${ }^{89}$ Some, however, had no connections whatsoever and tried their luck. This failed for Thomas Scott in 1672 in Dunkirk where he and his fellow travellers 'were admitted to the sight of nothing but the chapel'. ${ }^{90}$ Joseph Taylor, on the other hand, was more fortunate in Bruges in 1707. He had no recommendation, which he knew would be problematic to gain entrance to the convent, yet enquired for the lady abbess, who told him that 'if I desired to see any of them, she would intercede for me', a proposal he did not decline. ${ }^{91}$ In 1687, Thomas Penson also managed to engage in conversation with the religious women by stressing he was an Englishman. ${ }^{92}$ For countrymen the religious seemed to make an exception to their separation from the world..$^{93}$

\section{Conclusion}

Even though in his spy report Macky had been preoccupied with the danger the convents posed, as a traveller he was willing to embrace them as compatriots. None of the other travellers took advantage of their trip to the generally mocked Catholic cloisters to repeat juicy stereotypes either. Rather than writing along the lines of polemic, scorning an abstract evil, thus elaborating their anti-Catholic English identity, travellers encountered real-life individuals who did not always correspond to the well-known stereotypes. ${ }^{94}$

Instead, they depicted the nunneries as isles of a familiar culture in middle of a strange continent, and their inhabitants as outspoken English, not 'outlandish'. Pushing aside the confessional frictions that undoubtedly separated them, they let common ties prevail. They had the same historical background. They spoke the same language. They 
often even shared family ties. What connected them, not what separated them was therefore central when the compatriots met. Accordingly, travellers and nuns alike managed to find other ways of defining Englishness than the ones prescribed in polemical literature; ways that did not resort to excluding one another.

By consequence, the importance of anti-Catholicism, hailed by historians to be the founding principle of English national identity, could be qualified further. Undoubtedly, negative identity formation was of great importance, yet its explanatory strength only works within the confines of one close-knit group. By looking beyond these confines, at not only one dominant group, but the interactions between different interpretations of Englishness, it becomes clear that identity is more than defining what one is not. Englishness also encompassed positive elements, things Catholics and Protestants had in common. In confrontation with a common 'other', the Catholic continent, these shared elements gained importance.

\section{ABBREVIATIONS}

Primary Sources

Harwood, An Account

Leake, Diary of Occurrences

Percival, My Journy

Percival, My expedition

Macky, A journey

Penson, Penson's Short Progress

Scott, Iter Breve

Shaw, Letters to a nobleman

Skippon, An Account

Taylor, A relation
Brussels, Koninklijke Bibliotheek Albert I, ms. 4572 (II 2647), Harwood, An Account of my Ramble into Holland and the Low Countries begunn May the 9, 1697.

J. Leake, Diary of Occurrences and Observations Begun June the 15th O.S. 1711, in: C. D. Van Strien (ed.), Touring the Low Countries: Accounts of British Travellers, 1660-1720 (Amsterdam, 1998).

London, British Library, Additional Manuscripts: 47059 , fol. 19r-158v: J. Percival, My Journy to France, Holland and Flanders in 1718.

London, British Library, Additional Manuscripts: 47059, fol. 1-18r.: J. Percival, My expedition to Spain 1723.

J. Macky, A journey through the Austrian Netherlands (London, 1725).

T. Penson, Penson's Short Progress into Holland, Flanders and France, 1687, in: C. D. Van Strien (ed.), Touring the Low Countries: Accounts of British Travellers, 1660-1720 (Amsterdam, 1998).

T. Scott, Iter Breve, or a short and plain narrative of a journey from London to Antwerpe in Flanders, 1672, in: C. D. Van Strien (ed.), Touring the Low Countries: Accounts of British Travellers, 1660-1720 (Amsterdam, 1998).

J. Shaw, Letters to a nobleman, from a gentleman travelling thro' Holland, Flanders and France: with a description of Ghent, Lisle, \&c. and of the Courts of Versailles and St. Germains (London, 1709).

P. Skippon, An Account of a Journey made thro' part of the Low-Countries, Germany, Italy and France, in: A. Churchill and J. Churchill (ed.), A collection of voyages and travels, some now first printed from original manuscripts, VI (London, 1732), pp. 359-396.

J. Taylor, A relation of a voyage to the army: in several letters from a gentleman to his friend in the year 1707, in: C. D. Van Strien (ed.), Touring the Low Countries: Accounts of British Travellers, 1660-1720 (Amsterdam, 1998). 
Secondary Sources

Acosta, 'Hotbeds of Popery'

Bowden, 'The English Convents'

Clancy, 'Papist-Protestant-Puritan'

Claydon, Europe and the Making

Colley, 'Britishness'

Colley, Britons

Dolan, 'Why are nuns funny?'

Dolan, Whores of Babylon

Haydon, 'I love my King'

Haydon, Anti-Catholicism

Highley, Catholics writing the nation

Hill, 'A Refuge from Men'

Ihalainen, Protestant Nations Redefined

Lake, 'Anti-Popery’

Majérus, 'Une immigration spirituelle?'

Marotti, Religious Ideology

Netzloff, 'The English Colleges'

Shell, Catholicism, controversy

Van Strien, 'Recusant Houses'

Van Strien (ed.), Touring the Low Countries

Walker, 'Securing Souls'

Walker, Gender and politics

Zimpfer, 'Ecclesiastic anti-Catholicism'
A. M. Acosta, 'Hotbeds of Popery: Convents in the English Literary Imagination', Eighteenth-Century Fiction, 15 (2003), pp. 615-642.

C. Bowden, 'The English Convents in Exile and Questions of National Identity, 1600-1688', in: D. Worthington (ed.), Emigrants and Exiles from the Three Kingdoms in Europe, 1603-1688 (Leiden, 2010), pp. 297-315.

T. H. Clancy, 'Papist-Protestant-Puritan: English Religious Taxonomy 1565-1665', Recusant History, 13 (1976), pp. 227-253.

T. Claydon, Europe and the Making of England 1660-1760 (Cambridge, 2007).

L. Colley, 'Britishness and Otherness: An Argument', Journal of British Studies, 31 (1992), pp. 309-329.

L. Colley, Britons: Forging the Nation, 1707-1837 (New Haven, 1992).

F. E. Dolan, 'Why are nuns funny?', Huntington Library Quarterly, 70 (2007), pp. 509-535.

F. E. Dolan, Whores of Babylon. Catholicism, Gender, and Seventeenth-century Print Culture (Ithaca/London, 1999). B. Haydon, 'I love my King and my Country, but a Roman Catholic I hate': Anti-Catholicism, Xenophobia and National Identity in Eighteenth-Century England', in T. Claydon and I. McBride (eds.), Protestantism and National Identity: Britain and Ireland, 1660-1850 (Cambridge, 1998), pp. 33-52.

C. Haydon, Anti-Catholicism in Eighteenth-Century England. A Political and Social Study (Manchester, 1993). C. Highley, Catholics Writing the Nation in Early Modern Britain and Ireland (Oxford, 2008).

B. Hill, 'A Refuge from Men: the Idea of a Protestant Nunnery', Past and Present, 117 (1987), pp. 107-130.

P. Ihalainen, Protestant Nations Redefined. Changing Perceptions of National Identity in the Rhetoric of the English, Dutch and Swedish Public Churches, 1685-1772 (Leiden, 2005)

P. Lake, 'Anti-Popery: The Structure of a Prejudice', in R. Cust and A. Hughes (eds.), Conflict in Early Stuart England: Studies in Religion and Politics 1603-1642 (London, 1989), pp. 72-106.

P. Majérus, 'Une immigration spirituelle? Les maisons religieuses anglo-irlandais en Belgique (XVIIèmeXVIIIème siècles)', Tweede studiedag Belgische Kloostergeschiedenis (Bibliografische Inleiding tot de Belgische kloostergeschiedenis voor 1796; 39) (Brussels, 2001), pp. $125-139$

A. F. Marotti, Religious Ideology and Cultural Fantasy. Catholic and Anti-Catholic Discourses in Early Modern England (Indiana, 2005).

M. Netzloff, 'The English Colleges and the English Nation. Allen, Persons, Verstegan, and Diasporic Nationalism', in: R. Corthell e.a. (eds.), Catholic Culture in Early Modern England (Indiana, 2007), 236-260.

A. Shell, Catholicism, Controversy and the English Literary Imagination, 1558-1660 (Cambridge, 2001).

C. D. Van Strien, 'Recusant Houses in the Southern Netherlands as Seen by British Tourists $c .1650-1720$ ', Recusant History, 20 (1990), pp. 495-511.

C. D. Van Strien (ed.), Touring the Low Countries: Accounts of British Travellers, 1660-1720 (Amsterdam, 1998).

C. Walker, 'Securing Souls or Telling Tales? The Politics of Cloistered Spirituality', in: C. Van Wyhe (ed.), Female Monasticism in Early Modern Europe: An Interdisciplinary View (Aldershot, 2008), pp. 227-244.

C. Walker, Gender and Politics in Early Modern Europe: English Convents in France and the Low Countries (Basingstoke, 2003).

N. Zimpfer, 'Ecclesiastic anti-Catholicism in Britain after the Glorious Revolution', Via Panorâmica, 2 (2009), pp. 1-22. 


\section{NOTES}

1 This article is a revision of a paper read at the 2010 conference of the History of Women Religious on the British Isles. I would wish to thank the participants at the conference for their constructive insights, and Alexandra Walsham, Johan Verberckmoes and Violet Soen for their thought-provoking remarks on earlier drafts.

2 J. D. Alsop, 'John Macky's 1707 Account of the English Seminaries in Flanders', Recusant History, 15 (1981), pp. 338-339.

3 J. Macky, A journey, p. 195.

${ }^{4}$ London, British Library, Additional Manuscripts, 61601, J. Macky, 'Roman Catholics. States of English Seminaries in Low Countries 1707', fo. 179.

5 Alsop, 'John Macky's 1707 Account'; J. D. Alsop, 'Macky, John (d. 1726)', Oxford Dictionary of National Biography (Oxford, 2004), online version, accessed: 29th April 2010 [http://www.oxforddnb.com/view/article/17632].

6 Macky, A journey, pp. 4, 5, 18.

7 Macky, A journey, p. 18. Charlotte Bond (1690-1735): She was the daughter of Thomas Bond and granddaughter of Lord Jermyn. Her father had withheld her from entering the convent for years in a row. After giving in, he insisted on her staying in the Bruges foundation, as he lived in that town. His wish was not fulfilled, and Charlotte Bond became Teresa Joseph of the Sacred Heart of Jesus in Antwerp. Her father showed himself a great benefactor for his daughter's house. N. Hallett, Lives of Spirit: English Carmelite Self-Writing of the Early Modern Period (Aldershot, 2007), pp. 101-104.

8 Lady Lucy Herbert (1669-1744): She was the daughter of William Herbert (1617-1696), Duke of Powis. Her religious name was Sister Teresa Joseph. She was the sixth abbess of the English Augustines in Bruges, and author of the posthumously published Several Excellent Methods of Hearing Mass, With Fruit and Benefit (London, 1791); P. Guilday, The English Catholic Refugees on the Continent 1558-1795: The English Catholic Colleges and Convents in the Catholic Low Countries 1558-1795 (Louvain, 1914), p. 387; M. A. Mullett, English Catholicism, 1680-1830 (Brookfield, 2006), p. 47.

9 Van Strien, 'Recusant Houses'; Walker, Gender and Politics, pp. 97, 121; J. W. Stoye, English Travellers Abroad 1604-1667: Their Influence in English Society and Politics (London, 1989), 192.

10 C. Walker, 'Doe not supose me a well mortifyed Nun dead to the world: Letter-Writing in Early Modern English Convents', in: J. Daybell (ed.), Early Modern Women's Letter Writing, 1450-1700 (Basingstoke, 2001), p. 167; C. Walker, 'Securing Souls', pp. 103-130; C. Walker, 'Prayer, Patronage and Political Conspiracy', The Historical Journal, 43 (2000), pp. 1-23; C. Bowden, 'The Abbess and Mrs. Brown: Lady Mary Knatchbull and Royalist Politics in Flanders in the Late 1650s', Recusant History, 24 (1999), pp. 288-308; Walker, Gender and Politics, pp. 112-127.

11 Walker, Gender and Politics, p. 52; Van Strien, 'Recusant Houses'.

12 Walker, Gender and Politics, pp. 109-110, 121-122; C. Walker, 'Securing Souls or Telling Tales? The Politics of Cloistered Spirituality', in C. Van Wyhe (ed.), Female Monasticism in Early Modern Europe: An Interdisciplinary View (Aldershot, 2008), pp. 231-232; Majérus, 'Une immigration spirituelle', pp. 135-136; C. Walker, 'Priests, Nuns, Presses and Prayers: the Southern Netherlands and the Contours of English Catholicism', in B. J. Kaplan e.a. (eds.), Catholic Communities in Protestant States: Britain and the Netherlands, c. 1570-1720 (Manchester, 2009), p. 146.

13 The existence of the concept of nation before the nineteenth century is the object of fierce debates. For the sake of this article, however, 'national identity' should not be considered a well-confined ideology, but as a vague consciousness. See Christopher Highley's remarks on this: Highley, Catholics Writing the Nation, 2-5.

14 Haydon, Anti-Catholicism, 120-125; Ihalainen, Protestant Nations, 316.

15 Claydon, Europe and the Making of England, pp. 21-23; C. D. Van Strien, 'Thomas Penson: Precursor of the Sentimental Traveller', in Z. Von Martels (ed.), Travel Fact and Travel Fiction: Studies on Fiction, Literary Tradition, Scholarly Discovery and Observation in Travel Writing, Brill's Studies in Intellectual History; 55 (Leiden, 1994), p. 195; R. Sweet, 'The Changing View of Rome in the Long Eighteenth Century', Journal for Eighteenth-Century Studies, 33 (2010), p. 145; C. Haynes, 'A Trial for the Patience of Reason? Grand Tourists and Anti-Catholicism after 1745', Journal for Eighteenth-Century Studies, 33 (2010), p. 196.

16 Lake, 'Anti-Popery', pp. 73-74, 83. 
17 A. F. Marotti (ed.), Catholicism and Anti-Catholicism in Early Modern English Texts (New York, 1999); Marotti, Religious Ideology; Shell, Catholicism, Controversy; Colley, Britons, pp. 18-30; Haydon, Anti-Catholicism; Colley, 'Britishness and Otherness', p. 320; Zimpfer, 'Ecclesiastic Anti-Catholicism'; Haydon, 'I love my King', pp. 38-42.

18 H. Schilling, 'Nationale Identität und Konfession in Der Europaischer Neuzeit', in B. Giesen (ed.), Nationale Und Kulturelle Identität (Frankfurt am Main, 1991), 235-246; C. S. Dixon, 'Introduction: Living with Religious Diversity in Early-Modern Europe', in C. S. Dixon, D. Freist and M. Greengrass (eds.), Living with Religious Diversity in EarlyModern Europe (Surrey, 2009), pp. 12-13.

19 Colley, Britons.

20 J. C. D. Clark, 'Protestantism, Nationalism, and National Identity, 1660-1832', The Historical Journal, 43 (2000), pp. 249-276.

21 Claydon, Europe and the Making of England.

22 J. Black, 'Confessional State or Elect Nation?', in T. Claydon and I. McBride (eds.), Protestantism and National Identity: Britain and Ireland, 1660-1850 (Cambridge, 1998), pp. 53-74.

${ }_{23}$ Ihalainen, Protestant Nations Redefined, pp. 299-310; Haydon, Anti-Catholicism, p. 253; Colley, Britons, pp. 18-30; Haydon, 'I love my King', p. 49.

24 J. Gregory, 'Articulating Anglicanism: the Church of England and the Language of the Other During the Long Eighteenth Century', in N. Green and M. Searle-Chatterjee (eds.), Religion, Language and Power (New York, 2008), p. 145; Haydon, 'I love my King', p. 49. 25 Gregory, 'Articulating Anglicanism', p. 145; Haydon, 'I love my King', pp. 33, 49; Lake, 'Anti-Popery', pp. 72-106; Haydon, Anti-Catholicism, 41; Colley, 'Britishness and Otherness'; Colley, Britons; Shell, Catholicism, Controversy, p. 19; Ihalainen, Protestant Nations Redefined, p. 306.

26 A. Walsham, Providence in Early Modern England (Oxford, 1999), pp. 250-255, 280; Dolan, Whores of Babylon.

27 Colley, Britons, pp. 19, 30-43; Haydon, Anti-Catholicism, pp. 94-95, 136-137; Haydon, 'I love my King', p. 52.

28 Haydon, 'I love my King', p. 39; Colley, 'Britishness and Otherness', p. 320.

29 Walsham, Charitable Hatred: Tolerance and Intolerance in England, 1500-1700 (Manchester, 2006), p. 319.

30 Cited in: Clancy, 'Papist-Protestant-Puritan', p. 228.

31 Haydon, Anti-Catholicism, pp. 4-5, 27-28, 42-43; Clancy, 'Papist-Protestant-Puritan', pp. 228-232; Zimpfer, 'Ecclesiastic anti-Catholicism', p. 17; Dolan, Whores of Babylon, pp. 37-42, 54-55; Highley, Catholics Writing the Nation, p. 157; Shell, Catholicism, Controversy, p. 19; Ihalainen, Protestant Nations Redefined, p. 306; Haydon, 'I love my King', pp. 35-36, 39.

32 Walsham, Charitable Hatred, p. 127.

33 Clancy, 'Papist-Protestant-Puritan', 232.

34 Black, 'Confessional State or Elect Nation?', pp. 59, 72-73.

35 Netzloff, 'The English Colleges', p. 236.

36 Claydon, Europe and the Making.

37 W. Frijhoff, 'Shifting Identities in Hostile Settings', in B. Kaplan e.a. (eds.), Catholic Communities in Protestant States: Britain and the Netherlands, c. 1570-1720 (Manchester, 2009), p. 3.

38 Bowden, 'The English Convents in Exile', pp. 297-315.

39 Netzloff, 'The English Colleges'; Highley, Catholics Writing the Nation, pp. 23-53, 80-117.

40 Walker, Gender and Politics, p. 40.

41 N. Hallett, Lives of Spirit: English Carmelite Self-Writing of the Early Modern Period (Aldershot, 2007), p. 2; Bowden, 'The English Convents in Exile'; Majérus, 'Une immigration spirituelle', p. 126.

42 Highley, Catholics Writing the Nation, p. 183.

43 Highley, Catholics Writing the Nation, p. 182; Majérus, 'Une immigration spirituelle', p. 126.

44 Bowden, 'The English Convents in Exile'. As did many of the colleges and male religious foundations: P. Davidson, 'Recusant Catholic Spaces in Early Modern England', in R. Corthell e.a. (eds.), Catholic Culture in Early Modern England (Notre Dame, 2007), pp. 22-27.

45 Dolan, 'Why are nuns funny?', p. 525; Acosta, 'Hotbeds of Popery', pp. 616, 627. That this stereotype could influence real life is apparent in the fortunes of Mary Knatchbull. The abbess had come to Charles II's assistance during his exile. She had hoped to receive good 
payment once the Stuarts had regained their throne. However, the King was compelled to keep silent about the nun's crucial support. Not only would the idea of Catholic help infuriate his subjects, particularly Knatchbull's social status turned her into a ridiculous figure, 'the archetypal foolish woman'. C. Walker, 'Prayer, Patronage and Political Conspiracy', The Historical Journal, 43 (2000), pp. 22-23.

46 Harwood, An Account, fo. 185.

47 Shaw, Letters, p. 75. Other examples: J. Walker, 'A voyage Begunn in August Ann ${ }^{\circ}$ 1671', in: Van Strien (ed.), Touring the Low Countries, p. 100; E. Brown, Edward Browne's Journey of 1668, in: C. D. Van Strien (ed.), British Travellers in Holland During the Stuart Period: Edward Browne and John Locke as Tourists in the United Provinces (Leiden, 1993), p. 269.

48 W. Carstairs, Journal of a tour by Mr. William Carstairs, afterwards Principal Carstairs in the Low Countries, in 1685, in: W. Mure (ed.), Selections from the Family Papers Preserved at Caldwell (Glasgow, 1854), pp. 162-163.

49 London, British Library, Ms Stowe 790, Anonymous traveller, 'Account of a Journey from London through France, along the Rhine, the Low Countries and Back'. Cited in: Van Strien, 'Recusant Houses', p. 504.

50 Macky, A journey, p. 52.

51 Skippon, An Account of a Journey, p. 363.

52 Skippon, An Account of a Journey, p. 370.

53 For a small selection: Penson, Penson's Short Progress, p. 58; Harwood, An Account, fo. 196; Taylor, A relation, in: C. D. Van Strien, Touring the Low Countries, p. 105; Macky, A journey, p. 18.

54 Dolan, 'Why are nuns funny?', pp. 514-515; Acosta, 'Hotbeds of Popery', pp. 626-628.

55 Dolan, 'Why are nuns funny?', p. 522.

56 Penson, Penson's Short Progress, p. 59. For another clear example: J. Taylor, A relation of a voyage to the army: in several letters from a gentleman to his friend in the year $1707, \mathrm{C} . \mathrm{D}$. Van Strien (ed.) (Leiden, 1997), p. 119.

57 Taylor, A relation in: C. D. Van Strien (ed.), Touring the Low Countries, p. 119.

58 Taylor, A relation, in: C. D. Van Strien (ed.), Touring the Low Countries, p. 105.

59 Hill, 'A Refuge from Men', pp. 107-130; S. Lamb, Bringing travel home to England: tourism, gender, and imaginative literature in the eighteenth century (Delaware, 2009), p. 228. 60 G. Burnet, History of his Own Time, II (London, 1734), p. 653. Cited in: Hill, 'A Refuge from Men', p. 118.

61 Mary Astell stressed that the 'Piety shall not be roughly impos'd, but wisely insinuated'. (M. Astell, A Serious Proposal to the Ladies, 2 pts. (London, 1696), I, 40. Cited in: Hill, 'A Refuge from Men', 109.)

62 Hill, 'A Refuge from Men', 108.

63 E. Stols, 'De Oostenrijkse Nederlanden in de kijker van de buitenlanders', in: H. Hasquin (ed.), Oostenrijks België 1713-1794. De Zuidelijke Nederlanden onder de Oostenrijkse Habsburgers (Brussels, 1987), p. 526.

64 Leake, Diary of Occurrences, p. 281.

65 'if they think fit of altering their conditions from a single to a married life without being subject to the least reproach for so doing'. (Leake, Diary of Occurrences, p. 281.)

66 Macky, A journey through the Austrian Netherlands, p. 13.

67 Shaw, Letters to a nobleman, p. 92.

68 J. Northleigh, Topographical descriptions: with historico-political, and medico-physical observations: made in two several voyages, through most parts of Europe (London, 1702), pp. $156-157$.

69 The male English religious on the continent likewise attempted to convert their visiting Protestant compatriots. This can for instance be illustrated in the rich correspondence between English Jesuits in Paris and Rome on the high-profile attention to be accorded to David Murray, second Lord Balvaird, since 'all sorte of courtesy exhibits to such persons, may in tyme, do much good, and no harme at all'. (E. Chaney, The Grand Tour and the Great Rebellion. Richard Lassels and 'The Voyage of Italy' in the Seventeenth Century (Geneva, 1985), 100-107.)

70 Percival, My Journy, fo. 35v.

71 Skippon, An Account of a Journey, p. 370

72 Skippon, An Account of a Journey, p. 384.

73 Penson, Penson's Short Progress, p. 59.

74 For only a handful of examples of what could add up to a page long list: Harwood, $A n$ Account, fo. 167; Leake, Diary of Occurrences, p. 162. 
75 J. Black, Italy and the Grand Tour (New Haven, 2003), p. 167.

${ }^{76}$ Scott, Iter Breve, p. 139.

77 'Their convent is seated upon riseing ground; in a remote quiet part of ye city, this was one of ye first religious houses yt was founded abroad for our countrywomen... we iust complemented one or two of 'em thro ye nich of thir greate, I beleive we happen'd to come in prayer thime, they excus'd thir not receiving us more civilly, telling us, they should be glad to see us any afternoon'. (Harwood, An Account, fo. 167.)

${ }^{78}$ E. Brown, Dr. Brown's travels thro' divers parts of Europe, in: A. Churchill and J. Churchill (eds.), A collection of voyages and travels, some now first printed from original manuscripts, III (London, 1732), p. 525. Other examples: Brown, travels thro' divers parts of Europe, pp. 540, 541; Shaw, Letters to a nobleman, pp. 84, 85.

79 Shaw, Letters to a nobleman, p. 67.

80 E. Prideaux, Journal of a continental tour, 1711-1712, in: C. D. Van Strien (ed.), Touring the Low Countries, p. 280; Brown, Edward Browne's Journey of 1668, p. 269; Harwood, An Account, fo. 147; Percival, My Journy, fo 29v; Taylor, A relation in: Touring the Low Countries, p. 118; Scott, Iter Breve, p. 102.

${ }^{81}$ Macky, A journey, p. 61.

${ }^{82}$ Macky, A journey, pp. 61, 135

83 'The Appartments of the Abbot, and the Religious, are of the utmost Magnificence, and one of the Churches is a very fine Piece of Architecture, large, regular, and well adorn'd'. (Macky, A journey, p. 135.) 'That of Tongerlo is more like a Town than an Abbey, consisting of four great Squares, with a large Garden and a Park... That of Everbode, is as big, and will be finer, because their beautiful Church was rebuilt in 1673, and their whole Abbey is now rebuilding'. (Macky, A journey, p. 61.)

${ }^{84}$ Macky, A journey, pp. 18-19.

85 Macky, A journey, p. 52.

86 Penson, Penson's Short Progress, pp. 58-59.

87 Leake, Diary of Occurrences. Cited in: Van Strien, 'Recusant Houses', p. 505.

${ }^{88}$ English did seek each others' company while abroad. John Percival, for instance, explicitly mentioned this: 'indeed the pleasure that persons of the same country have to meet in foreign countrys prompts them to rejoyce with each other, and it is impossible for them when not extraordinary sick to forbear enjoying each others company' (Percival, My expedition, fo. $4 \mathrm{v}$.) His stay in Spa resulted in contacts with only two 'foreigners', whereas his list of English friends and acquaintances was endless. (Percival, My expedition, fo. 5v.) Elizabeth and Mary Burnet could not rely on as exhaustive a circle of friends as Percival's, yet did restrict themselves to English contacts: 'Lady Napier and Lady Webb are here, which are all English, and that is all the company my mother visits'. (M. Burnet, Diary kept during a journey with Mrs. Burnet, in: Van Strien (ed.), Touring the Low Countries, p. 246.) In Brussels, entertainment for English particularly was provided for. Joseph Taylor for example enjoyed himself at the Sablon, "where was a large assembly of our nation, but very few of the inhabitants'. Harwood as well was treated 'a particular entertainment for our Countrymen' launched by Mr. Hill, then English diplomat in Brussels. (Harwood, An Account, fo. 165.) As with the visits to the nuns, travellers never mentioned the religious ideas of their compatriots, whom they merely described as 'countrymen'. (Some examples: W. Mure, Journal of the Travels in England and the Low Countries, in: W. Mure (ed.), Selections from the Family Papers Preserved at Caldwell (Glasgow, 1854), p. 177; Leake, Diary of Occurrences, p. 67; Percival, My expedition, fo. 2v; J. Walker, A voyage Begunn in August Ann 1671, in: Van Strien (ed.), in Touring the Low Countries, pp. 308-309.) Only John Percival was an exception to this. He wrote about Mr Hudson in Ghent that he was 'an English gentleman settled there. He was then a protestant but afterwards changed his religion'. (Percival, My Journy, fo. 37r.) Nevertheless, during Percival's stay in the Southern Netherlands, Hudson fitted the idea that being English equalled being protestant. His guide in Bruges, however, was Mrs. Blount who was according to Percival 'a lady of very good sense \& remarkable wit', yet 'rigorous \& begotted a papist'. (Percival, My Journy, fo. 29v.) In Brussels the Irish Major North showed him around the town. This man was also 'a papist'. (Percival, My expedition, fo. 2v.)

${ }^{89}$ Leake, Diary of Occurrences, p. 68; Shaw, Letters to a nobleman, 75; Harwood, An Account, fo. 147.

90 Scott, Iter Breve, p. 139.

91 Taylor, A relation, Van Strien (ed.), Touring the Low Countries, p. 104.

${ }_{92}$ Penson, Penson's Short Progress, p. 58. 
93 The same can be said about the male communities. In Liège, for instance, Theophilus Dorrington was 'civilly, and easily admitted, upon saying only that we were Englishmen' by the English Jesuits. (T. Dorrington, Observations concerning the Present State of Religion in the Romish Church with Some Reflections upon them, Made in a Journey Through some Provinces of Germany in the Year 1698 (London, 1699), p. 241.)

94 Claire Haynes noted this phenomenon with regard to British travellers to Italy. They often elaborated on the stereotype of greedy clerics, yet related as often about intriguing encounters with individual good-hearted clerics. (C. Haynes, 'A Trial for the Patience of Reason? Grand Tourists and Anti-Catholicism after 1745', Journal for Eighteenth-Century Studies, 33 (2010), 199-202.) 